\title{
IMPROVEMENT OF THE PSYCHO-EMOTIONAL STATE OF PARAOLYMPIC SHOOTERS
}

\author{
Tatyana Andonova
}

\begin{abstract}
Summary
Successful performance of an athlete in the extreme conditions of the sports competitions depends to a certain extend on the individual psychological features and the ability to master one's own status.

One of the possible ways for psychoregulation of athletes is the combined methodology developed by us, which consists of three parts: massage of the head, massage of neurolimphatic reflexes, influence on neurovascular reflexes on the forehead and the initial and final points of the meridians on the face.

The aim of our study was to acquaint and train paralympic shooters with effective methods which they could use on their own for dealing with anxiety and regulating their emotional state.

The subject of our study were eight paralympic shooters within the framework of the scientific project with athletes with physical disabilities. The proposed methodology includes 5 procedures performed every other day with each of the athletes. In order to objectify its effects, immediately before and after the first and last procedure, the investigated subjects had to complete two psychological tests for Spitberg's situational anxiety and the emotional state of Wesman and Ricks. The second test included the following indicators - "Tranquility-anxiety", "Energy-fatigue", "High moodsuppressed", "Self-confidence- helplessness" and a total assessment of the emotional state.

The results of our study show an improvement of all the indicators we tested in both the first and the last procedure. Advantages of our combined method are that it takes a little time (7-10), it can be done on its own and in a pre-start situation only the third part is proposed to be performed for 1 to 3 minutes.
\end{abstract}

Key words: combined methodology, psychoregulation, paralympic athletes

\section{Introduction}

High sports achievements are associated with athlete's ability to prepare psychologically for showing one's highest result directly in competition. Sport competition is an environment which can elicit intense emotions. In shooting the requirement of good physical and psychological condition as well as technical perfection is highly demanded.

An important aspect of correct regulation of pre-start status is the use of self-regulation skills (Вяткин, Б. А., 1974, Платонов, В.Н., 1986). This ability provides the ability to withstand various confounding factors, not only biological nature fatigue, but also, first of all, psychological - uncertainty and fear.

In psychological literature the question of mental regulation in athletes is widely developed. Various methods of impact are offered: development of self-assurance and self-confidence (Костанян, A. O., 1987), "Verbal-musical psychoregulation" (Горбунов, Г. Д., 1994, Некрасов, В. П, 1986), formation of the world outlook, suggestion and self-suggestion, control and self-control, as well as opportunities for physiotherapy, psychopharmacology and electrostimulation (Попов, А. Л., 1998) О.В. Дашкевич (1970) divide the methods for the emotional adjustment into two groups: 1. Methods, with primary influence on mental functions: effects through inner speech and 2. Methods, with a primary effect on the physiological mechanisms of emotions, mainly through their muscular-motor component.

One of the possible ways for psychoregulation of athletes is the combined methodology developed by us.

\section{Aim and Objectives of the study}

The aim of our study was to acquaint and train paralympic shooters with effective methods for Self-regulation of the emotional state which they could use on their own.

The study was part of the scientific project "Tracking the Effects of Complex Interventional Effects in Sports Shooters" conducted at the NSA in June 2014. There were 8 paralympic shooters athletes involved with various motor disabilities. Their distribution by gender and age is given in table 1 . 
Table 1

Sex, age and sports experience of the persons studied

\begin{tabular}{|l|l|l|l|}
\hline Sex & N & Age & Sports experience \\
\hline Men & 5 & 33,8 & 3,5 \\
\hline Women & 3 & 44,7 & 6,7 \\
\hline
\end{tabular}

\section{Methods}

Our combined methodology consists of three parts: 1. Massage of the head - reduces stress and mental stress, and has a local analgesic effect.

2. Massage of neurolymphatic reflexes (NLR) of the back (Thie, J., Thie, M., 2006) has a predominantly somatic effect, improving the lymph flow in the associated muscles and organs.

3. Influence on nevrovascular reflexes (NVR) on the forehead (Walther, D., 2006) and the initial and final points of the meridians on the face - has a balancing effect on the emotional sphere.

The athletes were given 5 procedures every other day (by the author and by students trained by her), completing two questionnaires before and after the first and last procedure - Spitberg's situational anxiety (Angelova, Krastev, 1998) and the emotional state of Wesman and Ricks (Иванов, И., 1999). The second test included the following indicators -

"tranquility-anxiety" (T-A), "energy-fatigue" (EF), "high mood-suppressed" (HM-S), "self-confidence- helplessness" (SC-H) and a total assessment of the emotional state.

For statistical processing of the results, the SPSS software product was used. Variational analysis of the data was made. To determine the statistically significant difference (level of significance $\boldsymbol{\alpha} \leq 0,05$ ) in the results obtained, we used the Nonparametric statistics: Related samples Wilcoxson Signed Rank test and Independent Samples Mann-Whitney U test.

\section{Results}

\section{Situational anxiety}

Although there was no statistically significant difference in baseline with respect to reactive anxiety between the first and the second study, we can note that before the last procedure the anxiety of the athletes was lower (figure 1). In both studies, immediately after the massage, the values of situ- ational anxiety reached almost the same low level. We found that the increase in this indicator in both studies was statistically reliable (first day $-\boldsymbol{\alpha}=0,018$, last day $-\boldsymbol{\alpha}=0,012$ ).

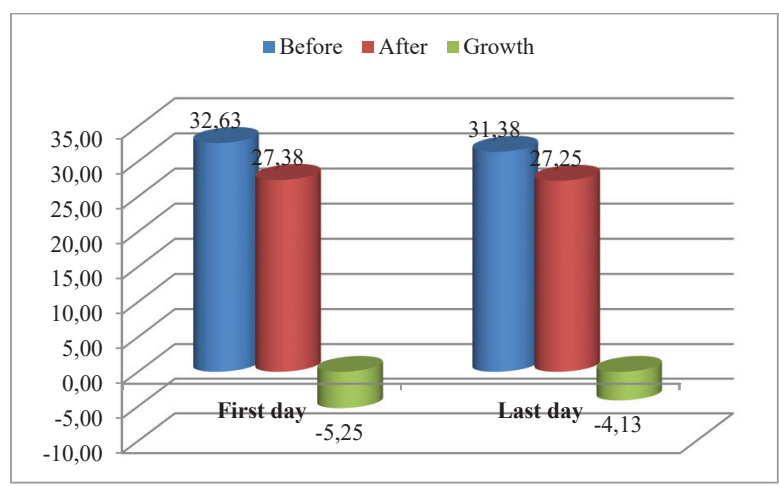

Figure. 1. Situational anxiety

\section{Emotional state}

The emotional state of the athletes (figure 2) has credibly improved, both after the first $(\alpha=0.012)$ and after the last procedure $(\alpha=0.012)$. Although there was no statistically significant difference between the emotional states before the two studies, it is better before the second. After both studies, the values of this indicator reached high levels, with the emotional state being better after the second study again, but without a credible difference between them.

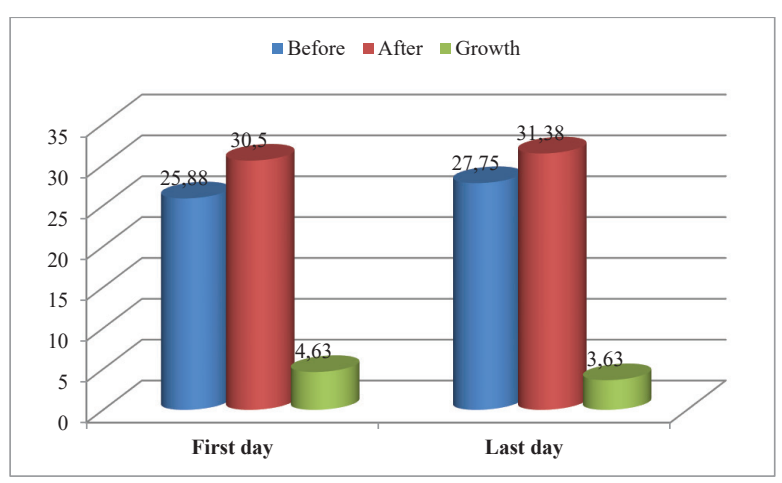

Figure 2. Emotional state

\section{Tranquility-anxiety}

The massage method applied by us, credibly improved the self-assessment of the competitors in the first $(\alpha=0.016)$ and second $(\alpha=0.011)$ measurements of this indicator, the growth in both being absolutely equal (figure. 3). Although there was no statistically significant difference in two baseline and two terminal statuses in this sign, we found a better baseline in the second. 


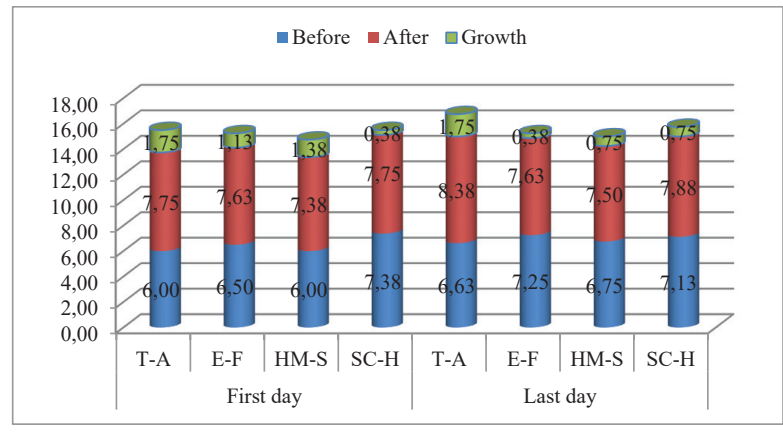

Figure 3. Subscales from the emotional state test

\section{Energy-fatigue}

Activity increased in both tests but statistically significant only in the first $(\alpha=0.02)$. The values of this indicator at the end of the two measurements are the same (figure 3 ).

\section{High mood-suppressed}

The mood credibly improved in both tests (first $\alpha=0,015$, second $-\alpha=0,034$ ), reaching higher values in the second (Figure 3 ). There was no significant difference between the two initial and the two final results.

\section{Self-confidence- helplessness}

Following our methodology, self-confidence increases both days of testing, but none is statistically reliable (Figure 3).

\section{Discussion}

The methodology was applied for the first time to students from the NSA "Vassil Levski", which was with a positive influence on both the emotional state and the situational anxiety was found (Andonova, 2014). In the present study, an improvement of all tested indicators was found, with most of them being statistically significant.

Decreasing anxiety and increasing serenity is an important prerequisite for the athletes' performance of all sports, and for shooters it is essential because it critically influences the accuracy and speed of the shots. In our study, we found a significant decrease in situational anxiety following the application of our methodology in both tests. Of the 4 tested subscales from the emotional states test, the highest values were reached for the indicator "Tranquility-anxiety" in the second study. The greatest improvement was found in the same index in both the first and second tests.

The lack of a statistically significant increase in the fourth indicator "Self-confidence- helplessness" can be explained by the fact that it characterizes not only the emotional state but also the cognitive sphere, for which a longer impact is needed.

None of the metrics we're examining reach high-boundary values, indicating an optimal improvement in psychic adaptation capabilities.

\section{Conclusion}

The effectiveness of the methodology proposed by us can be explained by its complex influence - the emotional and the somatic sphere.

The procedure does not take much time (7-10 minutes) and can be performed independently, because the NLR on the back corresponds to those on the front surface of the body, available for self-massage. In the pre start situation, it may be sufficient to perform only the third part of the procedure, which takes 1-3 minutes.

\section{References}

Angelova, R. L. Krastev (1998) Psihologicheski testove. Blagoevgrad, p. 107-109 // Ангелова, Р., Л. Кръстев (1998) Психологически тестове. Благоевград, с. 107-109.

Andonova, T. (2014) Metodika za namaliavane na stresa I trevojnostta, Sport I nauka, 4, s. 103-107 // Андонова, T. (2014) Методика за намаляване на стреса и тревожността. // Спорт и наука, 4, с. 103-107.

Вяткин, Б. А. (1974) Диагностика и регулирование психического состояния

спортсмена в соревнованиях. Пермь, с. 59.

Горбунов, Г.Д. (1994). Психодиагностика физического воспитания и спорта: автореф. дис. Санкт-Петербург, с. 58.

Дашкевич, О.В. (1970) Эмоции в спорте и их регуляция. автореф. дис. М., с. 24.

Иванов, И. (1999) Методики за изследване на функционалните състояния. Шумен, 31-33.

Костанян, А.О. (1987) Об особенностях психического состояния в спорте высших достижений. Тезисы. 16 республ. науч.- метод. конф, Ереван, с. 110-111.

Некрасов, В.П. (1986). Всегда в хорошем настроении: методы психорегуляции. Физкультура $u$ спорт, с 31 . Платонов, В.Н. (1986) Подготовка квалифицированных спортсменов. Физкультура $u$ спорт, с. 286.

Попов, А.Л. (1998) Спортивная психология: учебное пособие для физкультурных вузов. Флинт, с. 152.

Thie, John, M. Thie (2006). Touch for health. CA, DeVoss \& Company, p. 50-52.

Walther, D. Applied Kinesiology. Sinopsis. (2000).Colorado, Systems DS, p. 48-49.

\section{Contact information}

Tatyana Andonova, Asist. prof., Department of "Sports Medicine and Massage», National Sports Academy "Vassil Levski", Studentski grad, 1700, Sofia, taniaandonova@yahoo.com. 